\title{
Trophic structure and chemosynthesis contributions to heterotrophic fauna inhabiting an abyssal whale carcass
}

\author{
Joan M. Alfaro-Lucas ${ }^{1,3, *}$, Maurício Shimabukuro ${ }^{1}$, Isabella V. Ogata ${ }^{1}$, \\ Yoshihiro Fujiwara ${ }^{2}$, Paulo Y. G. Sumida ${ }^{1}$ \\ ${ }^{1}$ Instituto Oceanográfico, Universidade de São Paulo, Praça do Oceanográfico, 191, CEP 05508-120, São Paulo-SP, Brazil \\ ${ }^{2}$ Japan Agency for Marine-Earth Science and Technology - JAMSTEC, 2-15 Natsushimacho, Yokosuka 237-0061, Japan \\ ${ }^{3}$ Present address: Institut Français de Recherche pour l'Exploitation de la Mer (IFREMER), Centre de Bretagne, REM/EEP, \\ F-29280, Plouzané, France
}

\begin{abstract}
The trophic structure and role of chemosynthesis remain unexplored in deep-sea whale-fall communities in areas other than the California margin. This gap limits the understanding of these communities and their ecological relationships with other chemosynthetic ecosystems, such as vents and seeps. Here, we studied 3 different whale skeleton microhabitats with hypothesized high, intermediate and low reducing conditions as well as the sediments surrounding an abyssal whale fall (4204 $\mathrm{m}$ depth, SW Atlantic Ocean). We analyzed trophic structures $\left(\delta^{13} \mathrm{C}\right.$ and $\delta^{15} \mathrm{~N}$ ) and the contribution of chemosynthetically derived carbon to heterotrophic species. The high and intermediate reducing microhabitats harbored food webs dominated by consumers of chemosynthetic production, similar to those of diffusive areas of hydrothermal vents and seeps. Both the low reducing microhabitat and the sediments harbored food webs with greater trophic complexity, dominated by higher consumers mainly relying on whale and/or photosynthesis-derived organic matter, a type of food web commonly reported in small whale, wood and kelp falls. The main whale-fall ecosystem engineer, the boneeating worm Osedax, appeared to produce unique food web effects not observed in other chemosynthetic habitats. We conclude that whale falls provide the deep sea with a mosaic of microhabitats that supports assemblages with different chemosynthesis reliance levels and trophic structures, similar to those found at vents and seeps. Such a mosaic allows species-rich communities with numerous trophic levels to develop in a very small area of the food-limited deep sea.
\end{abstract}

${ }^{*}$ Corresponding author: joanmanel.alfaro@e-campus.uab.cat

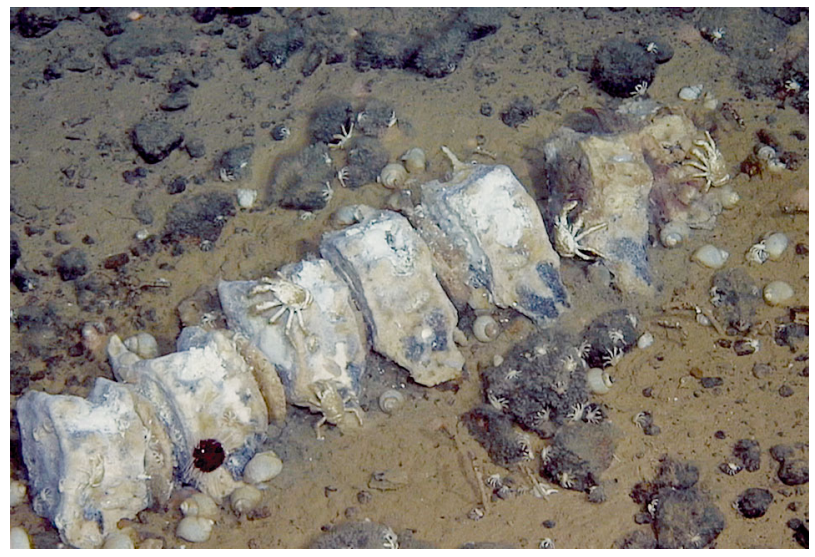

Whale carcasses provide the deep sea with a mosaic of microhabitats that support faunal assemblages with different trophic structures and chemosynthesis reliance levels.

Photo: Yoshihiro Fujiwara

KEY WORDS: Deep sea - Whale fall - Trophic structure $\cdot$ Chemosynthesis $\cdot$ Osedax

\section{INTRODUCTION}

In deep-sea environments such as hydrothermal vents and cold seeps, where reduced compounds are abundant, autochthonous microbial chemosynthetic production supports abundant endemic fau-

( ) The authors 2018. Open Access under Creative Commons by Attribution Licence. Use, distribution and reproduction are unrestricted. Authors and original publication must be credited. 
nal communities (Van Dover et al. 2002). At vents and seeps, unlike most of the vast, food-limited deep sea, photosynthetically derived food sources only supplement faunal diets. These food sources have decreasing importance with increasing depth, and the intensity of reducing compound fluxes within habitats affects their use (Levin \& Michener 2002, Levesque et al. 2006, Decker \& Olu 2012, Bernardino et al. 2012). Among chemosynthetic ecosystems, those derived from cetacean carcasses, the largest organic parcels exported from surface waters, may create conditions that support chemosynthesis for years and even decades (Smith \& Baco 2003, Smith 2006, Smith et al. 2015).

Although 'whale falls' are thought to be common along cetacean migratory routes, they were only discovered ca. 30 yr ago and have been much less studied than vents and seeps, especially in basins outside the Northeast Pacific Ocean (Smith et al. 1989, Smith et al. 2015). Carcasses greatly impact small areas of the seafloor $\left(\sim 100 \mathrm{~m}^{2}\right)$, attracting opportunistic and specialized fauna and creating unique island-like habitats considered to be hotspots of biodiversity and sources of evolutionary novelty (Smith et al. 2015). The organic matter in enriched sediments around carcasses and within the lipid-rich skeletons is anaerobically degraded by sulfate-reducing bacteria and archaea, which generate fluxes of reduced compounds as by-products of their metabolism (Deming et al. 1997, Smith \& Baco 2003, Goffredi et al. 2008, Treude et al. 2009). The free-living chemosynthetic sulfide-oxidizing bacteria and chemosymbiotic invertebrates that exploit these fluxes also occur in vents, seeps and other organic falls (Smith et al. 1989, Feldman et al. 1998, Fujiwara et al. 2007, Lundsten et al. 2010a,b, Smith et al. 2015). Heterotrophic fauna also colonize whale falls during the 'sulfophilic stage', creating extremely species-rich communities structured in several trophic levels (from 3 to 5) (Baco \& Smith 2003, Smith \& Baco 2003). Bone fauna assemblages are considered one of the most species-rich hard-substrate habitats in the deep sea (Baco \& Smith 2003).

Whale falls have been hypothesized to act as stepping stones for faunal evolution and dispersal among distant nascent seeps and vents (Smith et al. 1989, Smith et al. 2017, Kiel 2017). Some chemosymbiotic seep/vent fauna likely originated in shallow waters and potentially used organic falls to colonize the deep sea (Distel et al. 2000, Jones et al. 2006, Miyazaki et al. 2010, Lorion et al. 2013, Thubaut et al. 2013). Deep-sea chemosynthetic habitats, including whale falls, already face, or are very likely to face, anthropogenic impacts, such as fisheries and deep-sea mining (Roman et al. 2014, Levin et al. 2016). Therefore, understanding their ecological interactions is crucial for their effective protection (Roman et al. 2014, Levin et al. 2016). The trophic ecology of whale falls has received little attention beyond the deep California margin (Baco \& Smith 2003, Smith \& Baco 2003). This gap may bias our understanding of these habitats and their ecological links with vents, seeps and other organic falls from other basins. Previous studies report that large whale skeletons in the sulfophilic stage create communities that are similar to those of vents with 3 to 5 trophic levels (Baco \& Smith 2003, Smith \& Baco 2003). In the Pacific, the low $\delta^{15} \mathrm{~N}$ values in the fauna indicate local origins for much of the organic nitrogen (Smith \& Baco 2003). In the latter study, chemosymbiotic bivalves (Vesicomya gigas and Idas washingtonia) dominated macrofaunal abundance and constituted $58 \%$ of the molluscan biomass. Species that depend on chemosynthetic production accounted for up to $42 \%$ of the community biomass, with just a few species relying on the whale organic material (Smith \& Baco 2003). In contrast, small juvenile whale skeletons harbored communities mainly dependent on whale organic matter (Smith \& Baco 2003).

Here, we present a detailed stable isotope analysis $\left(\delta^{13} \mathrm{C}\right.$ and $\left.\delta^{15} \mathrm{~N}\right)$ of an abyssal whale-fall community (4204 m depth, off Brazil, SW Atlantic Ocean) at the sulfophilic degradation stage in order to shed light on the reliance of heterotrophic fauna from 3 skeleton microhabitats and sediments on microbial chemosynthetic production. The carcass in this study was a juvenile whale, and previous studies suggested that chemosynthesis may be important, especially in some parts of the skeleton (Sumida et al. 2016, Alfaro-Lucas et al. 2017). Based on visual observations and colonizing fauna, we hypothesized that a gradient in the sulfide concentration would define availability of chemosynthetic production across the skeleton microhabitats, in addition to the fauna from sediments. As reported for vents and seeps, we expected a decrease in faunal reliance on microbial chemosynthetic production from the hypothesized high to low reducing microhabitats. Specifically, in this study, we address the following questions: (1) is free-living microbial chemosynthetic primary production an important food source for heterotrophic species at whale-fall microhabitats; and (2) how does trophic structure vary among different whale-fall microhabitats and across the entire whale-fall community? 


\section{MATERIALS AND METHODS}

\section{Study site, sample processing and whale-fall microhabitats}

We studied a partial natural whale carcass discovered by the submersible HOV (human occupied vehicle) 'Shinkai 6500' during the Brazilian-Japanese Iatá-Piúna expedition, a part of the around-theworld Quelle 2013 project (Japanese Agency for Marine-Earth Science and Technology). The carcass was discovered at $4204 \mathrm{~m}$ depth at the base of São Paulo Ridge $\left(28^{\circ} 31.1191^{\prime} \mathrm{S}, 41^{\circ} 39.4097^{\prime} \mathrm{W}\right)$, off the SE Brazilian margin, SW Atlantic Ocean (Sumida et al. 2016). The juvenile Antarctic minke whale Balaenoptera bonaerensis carcass consisted of 9 caudal vertebrae of ca. $11.5 \mathrm{~cm}$ in diameter without soft tissues (Sumida et al. 2016) (Fig. 1). During 2 dives, the HOV 'Shinkai 6500 ' completed detailed video surveys and collected whale bones with its manipulators. The whale-fall location was characterized by a thin layer $(<20 \mathrm{~cm})$ of sediments overlying basaltic rocks, which complicated collection of sediment cores (Sumida et al. 2016). Sedimentary fauna were therefore collected immediately below and adjacent $(0.5 \mathrm{~m})$ to the carcass using a slurp gun.

Only sediments below the skeleton were dark in color, suggesting high concentrations of sulfide and anoxia (Allison et al. 1991, Sumida et al. 2016). Five of the 9 vertebrae were (1) still joined together by intervertebral discs, (2) significantly eroded only at the spinous and transverse processes, (3) colonized by dense white bacterial mats on their upper parts, (4) stained black at the parts closer to or in contact with the sediment and (5) not colonized by bone-eating Osedax worms (Sumida et al. 2016, Alfaro-Lucas et al. 2017). Based on image analysis and the distinct colonizing fauna, we hypothesized that these vertebrae provide 2 microhabitats (Alfaro-Lucas et al. 2017): (1) inferior parts of vertebra close to or in contact with sediments with blackish areas, suggesting high concentrations of sulfide and anoxia, and (2) superior parts entirely exposed to the water column and colonized by dense, white chemoautotrophic bacterial mats (hypothesized to be sulfide oxidizing bacteria), suggesting lesser anoxic and reducing conditions, i.e. a redox interface (Higgs et al. 2011) (Fig. 1A,B). The remaining 4 vertebrae were loose (not joined together by intervertebral discs), and colonized and heavily eroded by a single new species of Osedax (Sumida et al. 2016) (Fig. 1C). Although some thin and sparse bacterial mats were present on these bones, Osedax apparently prevented the formation of bacterial mats by decreasing sulfide concentrations by enhancing oxygen penetration to the inner-bone matrices (Alfaro-Lucas et al. 2017) (Fig. 1C). Vertebrae colonized by Osedax sp. were associated with different infaunal assemblages from those of non-colonized vertebrae (Alfaro-Lucas et al. 2017).

We analyzed carbon and nitrogen stable isotopes of infaunal species accounting for 97.5, 51.1 and $98.3 \%$ of the total faunal abundance of the inferior parts of the vertebrae not colonized by Osedax sp., the superior parts of the vertebra not colonized by Osedax sp. and the vertebra colonized by Osedax sp., respectively (see Table 1). The most abundant and large epifauna of sediments were also analyzed (Munidopsis sp. and Rubyspira sp.), and the total number of individuals in the community (not percent abundance) was obtained through video analysis (Sumida et al. 2016). We did not estimate abundances of sediment epifauna that were indistinguishable in video analysis, such as $B a-$ thykurila cf. guaymasensis and Bathyfauvelia sp. (Sumida et al. 2016). For sediment infauna, including nematodes and the new nereidid species Neanthes shinkai (Shimabukuro et al. 2017), we did not estimate abundances because we used a slurp gun instead of corers (Sumida et al. 2016) (see Table 1). On board, large infauna from bones (Osedax sp.) and epifauna of the sediments (Neanthes shinkai, Bathyfauvelia sp., Bathykurilla cf. guaymasensis and Rubyspira sp.) were sorted under a stereomicroscope and preserved in $99.5 \%$ non-denatured ethanol. Whale bones and sediments were both preserved in $99.5 \%$ non-denatured ethanol for further sorting of the fauna in the laboratory. In order to obtain reliable data for the vertebra infauna while considering superior and inferior microhabitats of vertebrae without Osedax, we removed selected rectangular pieces of the upper and lower parts of the vertebrae in the laboratory, using a saw (see detailed procedure in Alfaro-Lucas et al. 2017). Vertebrae colonized by Osedax did not exhibit such obvious microhabitats, and several randomly chosen pieces were removed from different parts of the colonizing vertebrae, also using a saw, to sample colonizing infauna (Alfaro-Lucas et al. 2017). All fauna was identified under a stereomicroscope to the lowest possible taxonomic level by expert taxonomists and preserved in $99.5 \%$ non-denatured ethanol.

\section{Stable isotope analyses, mixing models and species trophic positions}

We analyzed stable carbon and nitrogen isotopes of each species in triplicate, except for large or very 


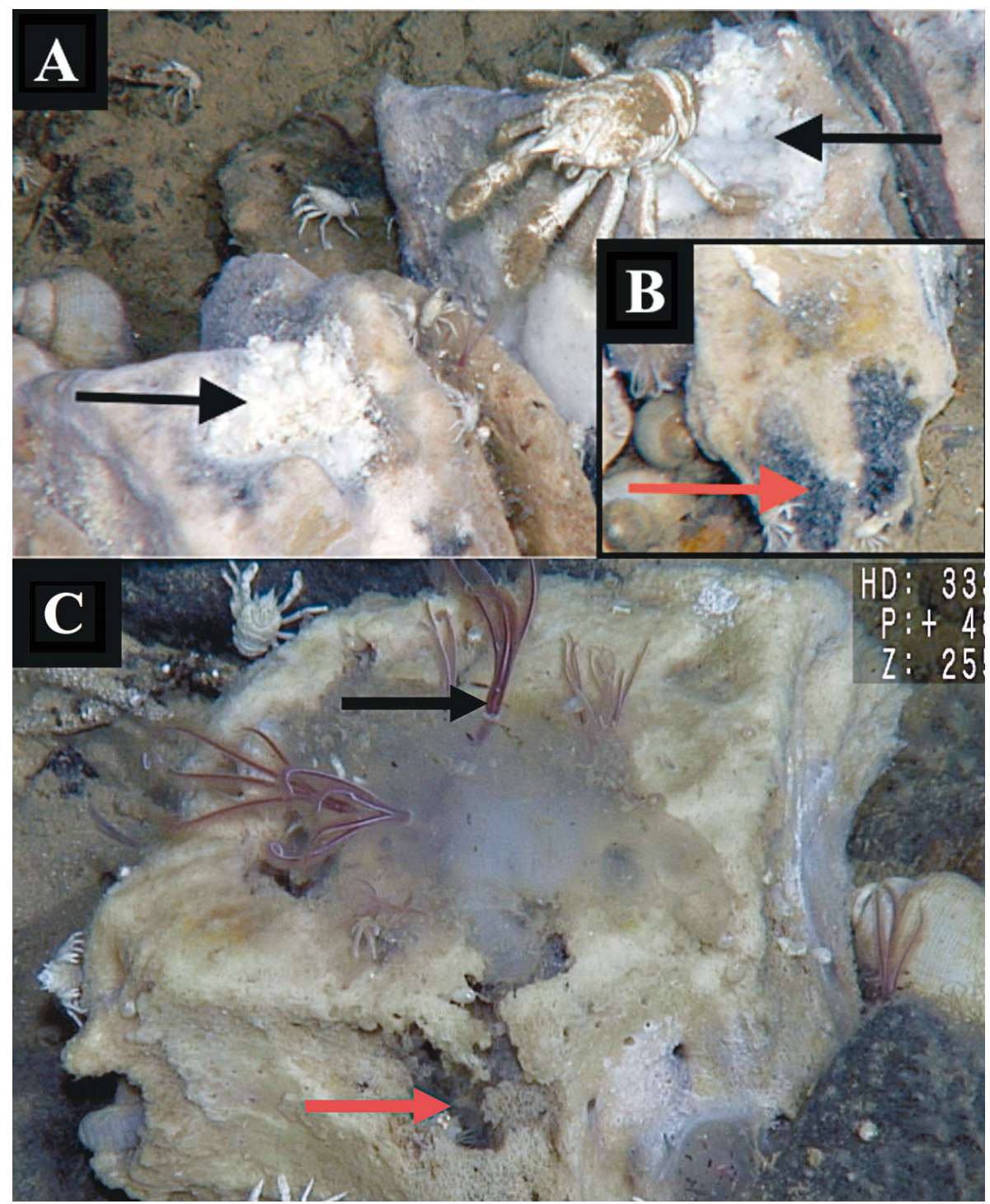

Fig. 1. Three different skeleton microhabitats at the whale-fall community at the base of São Paulo Ridge (4204 m), off Brazil, SW Atlantic Ocean. $(A, B)$ Vertebra not colonized by bone-eating Osedax worms, with inferior parts of vertebra in contact with or partially buried in sediments hypothesized to have highly reducing conditions, i.e. dark stains (red arrow), and superior parts entirely exposed to the water column inhabited by dense chemoautotrophic bacterial mats hypothesized to have intermediate reducing conditions (black arrows). (C) Vertebra colonized and bioeroded (red arrow) by Osedax sp. (black arrow) hypothesized to have low reducing conditions. Image modified from Sumida et al. (2016)

abundant species, such as Capitella iatapiuna, for which we removed 5 samples of pooled individuals from 5 different bones. Six samples belonging to 6 different individuals were sampled for Neanthes shinkai. For animals with low densities, such as Bathykurilla cf. guaymasensis and Bathyfauvellia sp. from the sediments, we analyzed only one sample of each species (Table S1 in the Supplement at www.int-res. com/articles/suppl/m596p001_supp.pdf). We did not remove the gut of very small species, and instead pooled individuals (5-10 individuals for polychaetes;
30-100 individuals for nematodes) in order to attain the minimum biomass required for isotopic analysis. For Neanthes shinkai, Osedax sp., Rubyspira sp., Munidopsis sp., Bathykurilla cf. guaymasensis and Bathyfauvellia sp., we used portions of single individuals for each sample. Given the presence of endosymbiotic bacteria in Osedax sp. roots and the possibility of symbiont presence in Rubyspira gills (Johnson et al. 2010), we used only parts of the trunk and the foot, respectively, for isotopic analysis. We obtained samples of all species from microhabitats of different 
bones whenever possible in order to evaluate the variability between bones (Table S1, in the Supplement). Nematodes were not identified to species level, and we treated samples as a representation of the nematode assemblage for each microhabitat.

Individuals or groups of individuals were rinsed in Milli-Q water, frozen, freeze-dried, weighed and encapsulated in tin boats. Samples were then transferred to a Costech Instruments Elemental Combustion System coupled to a Thermo Scientific Delta V Advantage Isotope Ratio Mass Spectrometer (EAIRMS) to measure stable isotopic composition. Carbon and nitrogen isotope results are expressed in delta notation:

$$
\delta X=\left[\left(\frac{R_{\text {sample }}}{R_{\text {reference }}}-1\right)\right] \times 1000
$$

where $X={ }^{13} \mathrm{C}$ or ${ }^{15} \mathrm{~N}$ and $R_{\text {sample }}={ }^{13} \mathrm{C} /{ }^{12} \mathrm{C}$ or ${ }^{15} \mathrm{~N} /{ }^{14} \mathrm{~N}$ (Peterson \& Fry 1987). We used Vienna Peedee Belemnite $\left(R_{\mathrm{VPDB}}=0.01118\right)$ as a reference $\left(R_{\text {reference }}\right)$ for carbon, and atmospheric $\mathrm{N}_{2}$ as a reference for nitrogen. Analytical precision based on the standard deviation of internal standard replicates was $0.05 \%$ for both $\delta^{13} \mathrm{C}$ and $\delta^{15} \mathrm{~N}$. We considered the effects of ethanol preservation to be negligible for the $\delta^{15} \mathrm{~N}$ analyses of the species (Fanelli et al. 2010, Lau et al. 2012). Although ethanol may potentially affect $\delta^{13} \mathrm{C}$ values, its effects are variable, taxon specific and usually more important in mollusks than in polychaetes or crustaceans, which limits the use of standard corrections. Therefore, we applied no correction factor (Fanelli et al. 2010, Lau et al. 2012), and analyzed only one mollusk in this study (Rubyspira sp.).

Chemosynthetic bacterial mats, whale vertebrae and sedimentary organic matter of photosynthetic origin (SOM) were used to estimate the dependence of consumers on chemosynthetic primary production. We estimated the percentage of the chemosynthetically derived carbon (CDC) of species with an isotope mixing model assuming no trophic shift for $\delta^{13} \mathrm{C}$ (Levin \& Michener 2002):

$$
\begin{aligned}
\mathrm{CDC} & =\left(\delta^{13} \mathrm{C}_{\mathrm{sp}}-\delta^{13} \mathrm{C}_{\mathrm{SOM}}\right) \\
& /\left(\delta^{13} \mathrm{C}_{\text {chemo bacteria }}-\delta^{13} \mathrm{C}_{\mathrm{SOM}}\right) \times 100
\end{aligned}
$$

where $\delta^{13} \mathrm{C}_{\mathrm{sp}}, \delta^{13} \mathrm{C}_{\mathrm{SOM}}$ and $\delta^{13} \mathrm{C}_{\text {chemo bacteria }}$ are the mean carbon isotopic values of species, SOM and chemosynthetic bacterial mats, respectively. Given that we could not collect chemosynthetic bacterial mats for this community, we used mats collected from the thorax vertebrae of a humpback whale Megaptera novaeangliae implanted in the same region (at $28^{\circ} 1.7^{\prime} \mathrm{S}, 43^{\circ} 31.8^{\prime} \mathrm{W}$ ) and water mass at $3300 \mathrm{~m}$ depth (Antarctic Bottom Water, $0.9^{\circ} \mathrm{C}$ and salinity of
34.7; Orsi et al. 1999). We used the isotope composition of SOM from North São Paulo Plateau sediments sampled in the same expedition (2692-2706 m depth, 2.51 to $2.63^{\circ} \mathrm{C}$ and salinity of 34.90 to 34.92 ) (Fujikura et al. 2017). For species that also consume whale organic matter, this model may overestimate CDC percentages $\left(\mathrm{CDC}_{\max }\right.$, see Table 1$)$ (Levin \& Michener 2002, Thurber et al. 2010). To address this issue, we replaced $\delta^{13} \mathrm{C}_{\mathrm{SOM}}$ in the model with the $\delta^{13} \mathrm{C}$ of whale bones $\left(\delta^{13} \mathrm{C}_{\text {whale }}\right)$, thus providing a conservative estimate of $\mathrm{CDC}\left(\mathrm{CDC}_{\min }\right.$, see Table 1$)$. We analyzed 3 distinct inner bone matrices completely depleted of lipids in order to obtain the vertebrae $\delta^{13} \mathrm{C}_{\text {whale }}$ and $\delta^{15} \mathrm{~N}_{\text {Whale. }}$. Because bone lipids were partially dissolved in $99.5 \%$ non-denatured ethanol, we decided to analyze the isotopic composition of vertebra matrices depleted of lipids, which are rich in organic compounds such as collagen, in order to obtain a reliable isotopic composition of whale organic matter.

For the different microhabitats and the overall community, we used the method proposed in Post (2002) to estimate the trophic position (TP) of each species:

$$
\mathrm{TP}=\lambda+\left(\delta^{15} \mathrm{~N}_{\text {consumer }}-\delta^{15} \mathrm{~N}_{\text {base }}\right) / \Delta n
$$

where $\delta^{15} \mathrm{~N}_{\text {chemo bacteria }}$ was used as a $\delta^{15} \mathrm{~N}_{\text {base }}$ (see Table 1). $\lambda$ is the trophic position of the organisms used to estimate $\delta^{15} \mathrm{~N}_{\text {base, }}$ which is represented by chemosynthetic bacteria in our study, so $\lambda=1$. $\delta^{15} \mathrm{~N}_{\text {consumer }}$ denotes the mean $\delta^{15} \mathrm{~N}$ of the species, and $\Delta n$ denotes the enrichment in $\delta^{15} \mathrm{~N}$ per trophic level, which was set at $3.4 \%$ (DeNiro \& Epstein 1981, Minagawa \& Wada 1984, Post 2002).

$\mathrm{CDC}_{\max }$ and TP values were compared for Capitella iatapiuna inhabiting the 3 putative skeleton microhabitats. We excluded samples from superior parts of vertebra not colonized by Osedax because they were obtained from the same bone and were not considered independent (Table S1). We tested normality and homogeneity of variance using ShapiroWilk and homogeneity of variance tests, respectively. All statistical analyses were performed in R (R Core Team 2014).

\section{RESULTS}

Nematode samples from inferior parts of the bones not colonized by Osedax (mean $=-30.13 \pm 0.28 \%$ ) contained the most depleted mean $\delta^{13} \mathrm{C}$ values of fauna, whereas the polynoid Bathykurila cf. guaymasensis from sediments contained the most enriched value $(-19.7 \%$; Fig. $2 \mathrm{~A}, \mathrm{C}$, Table 1$)$. The dorvilleid 
Ophryotrocha sp. 1 from the vertebrae bioeroded by Osedax was most depleted in $\delta^{15} \mathrm{~N}$ (mean $=4.87 \pm$ $1 \%$ ), whereas Osedax was most enriched (mean = $12.84 \pm 0.16 \%$; Fig. $2 \mathrm{~B}$, Table 1$). \delta^{13} \mathrm{C}$ and $\delta^{15} \mathrm{~N}$ standard deviations were generally low among the samples, except for the galatheid crab Munidopsis sp. from sediments, Pleijelius sp., and nematodes from the bones bioeroded by Osedax (Fig. 2B,C, Table 1). The isotopic values of food sources were clearly distinct (Fig. 2, Table 1). The mean $\delta^{13} \mathrm{C}$ and $\delta^{15} \mathrm{~N}$ of chemosynthetic bacterial mats were $-30.47 \pm 0.27 \%$ and $2.94 \pm 2.62 \%$, respectively. The isotopic composition of the organic matter of the whale vertebrae was $-24.04 \pm 0.47 \%$ and $7.36 \pm 0.24 \%$ o for $\delta^{13} \mathrm{C}$ and $\delta^{15} \mathrm{~N}$, respectively.

The maximum species CDC percentages ranged from $96.45 \pm 2.96 \%$ in nematodes from inferior parts of the vertebrae without Osedax to $2.93 \pm 1.17 \%$ in the gastropod Rubyspira sp. from sediments. Minimum values varied from $94.72 \pm 4.41 \%$ in nematodes from inferior parts of the vertebrae without Osedax to $0 \%$ in many species (Table 1). Most species from the vertebrae bioeroded by Osedax and sediments had zero CDC percentages (Table 1). The $\delta^{13} \mathrm{C}$ values in the polynoid Bathykurila cf. guaymasensis from sediments were greater than the SOM value; we did not calculate its CDC percentages (Fig. 2B,C, Table 1). TP values varied from 1.7 to 3.83 , with values for most species between 2 and 3 (Table 1).

The capitelid Capitella iatapiuna and nematodes were the dominant fauna in the 3 hypothesized microhabitats (Table 1). Nematode CDCs from highly reducing environments were ca. 5-6 times higher than those from low reducing environments and sediments. Moreover, significantly higher CDC percentages in $C$. iatapiuna occurred in putative high reducing compared to low reducing microhabitats ( $t=8.83$, df $=5, \mathrm{p}=0.0003$ ). Despite these values, we found no significant differences in their TP $(t=0.97$, df $=5, p=0.37)$ (Table 1).

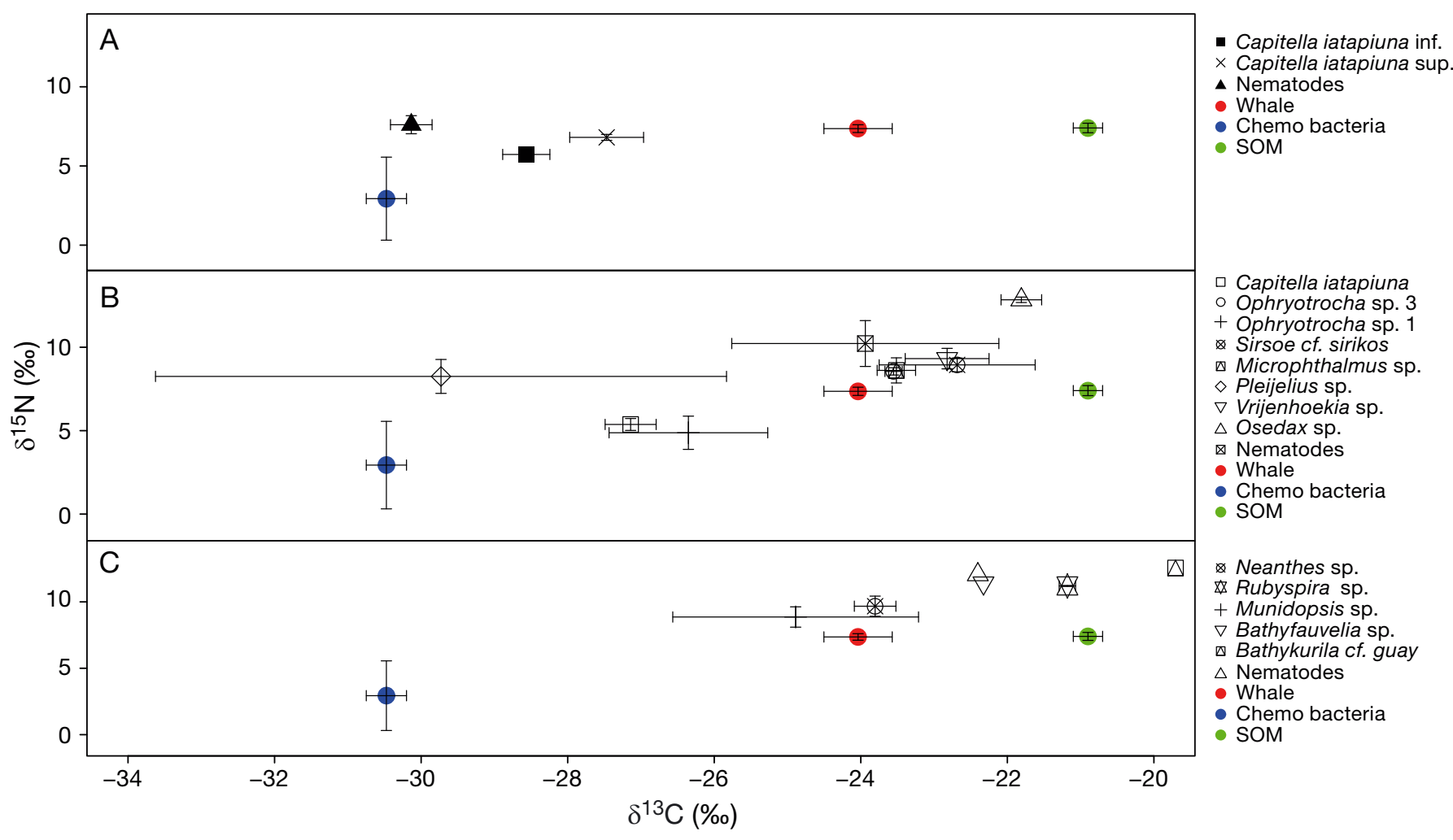

Fig. 2. Mean and standard deviations of $\delta^{13} \mathrm{C}$ and $\delta^{15} \mathrm{~N}$ isotope ratios of species and food sources in different whale-fall microhabitat assemblages. (A) Species from the hypothesized high (Capitella iatapiuna inf. and nematodes) and intermediate (Capitella iatapiuna sup.) reducing microhabitats. (B) Species of the putative low reducing skeleton microhabitat. Note that Ophryotrocha sp. 3 and Microphthalmus sp., and Sirsoe cf. sirikos and Vrijenhoekia sp. values, respectively, show considerable overlap. (C) Species from the sediments. Values for Bathykurila cf. guaymasensis, Bathyfauvelia sp. and nematodes were obtained from 1 sample each. Food sources, i.e. chemosynthetic bacterial mats (chemo bacteria), whale matter and sedimentary organic matter of photosynthetic origin (SOM) are indicated with blue, red and green filled circles, respectively. Capitella iatapiuna inf. and C. iatapiuna sup. refer to the species in the high and intermediate reducing microhabitats, respectively 


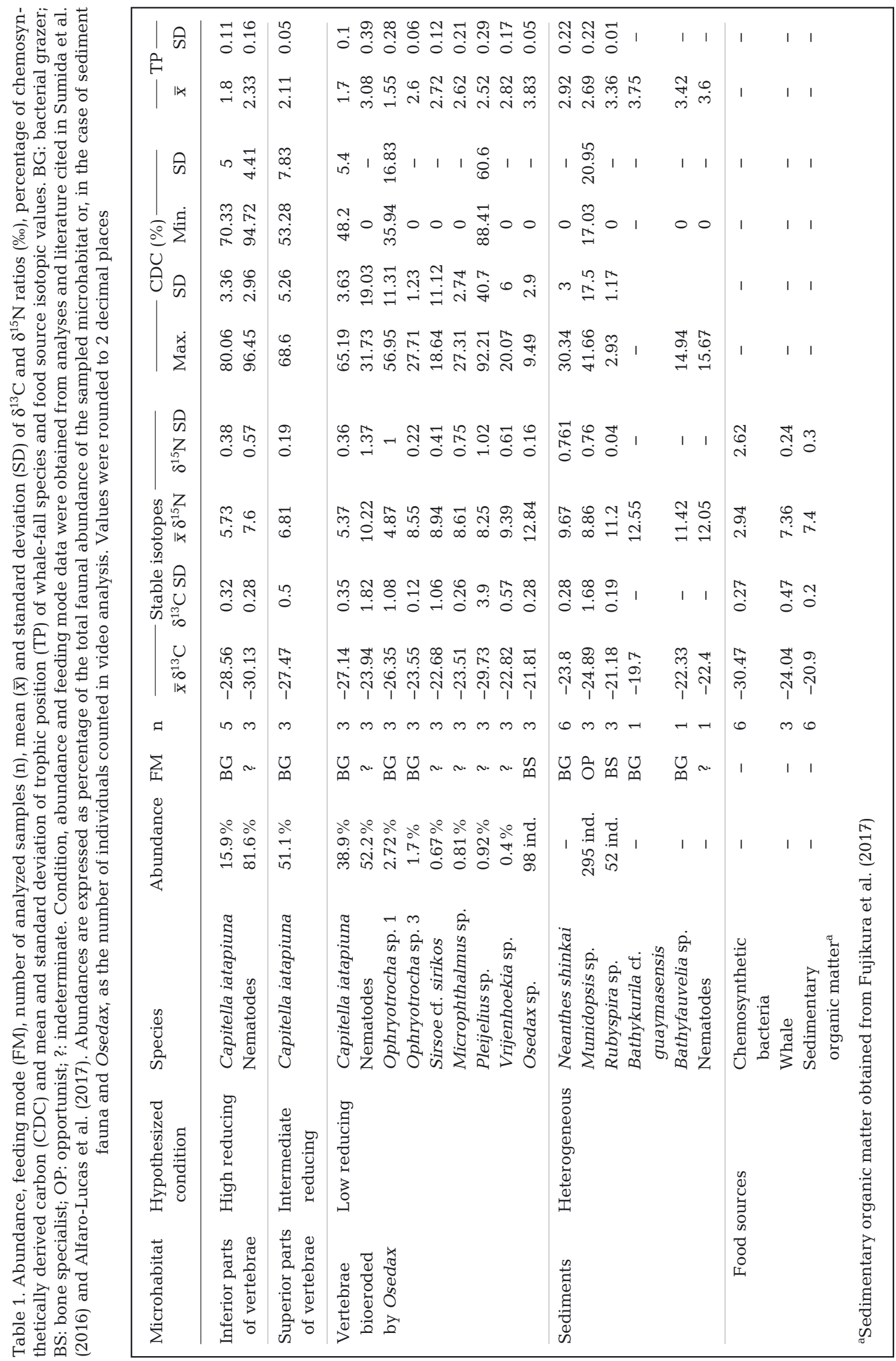




\section{DISCUSSION}

To date, the relative importance of chemosynthesis to late successional food webs has only been explored on whale falls from the California margin (Baco \& Smith 2003, Smith \& Baco 2003). The faunal communities of large whale falls depend predominantly on chemosynthesis-based food webs similar to those of some vents (Smith \& Baco 2003). Our study confirms the importance of organic matter of chemosynthetic origin as a food source in our juvenile whale carcass. We further show that the skeleton microhabitats in different reducing conditions exhibit varying levels of dependence on microbial chemosynthetic primary production with contrasting food web structures, such as those observed in vents and seeps (Levin \& Michener 2002, Levesque et al. 2006, Bernardino et al. 2012, Decker \& Olu 2012). This finding indicates that whale falls form a mosaic of different microhabitats that harbor distinct faunal assemblages in terms of species, dependence on chemosynthetic production, and trophic structure, which helps to explain the high biodiversity found in these restricted deep-sea habitats.

Although the $\delta^{13} \mathrm{C}$ and $\delta^{15} \mathrm{~N}$ values in chemosynthetic bacterial mats in the present study were lower than those of Smith \& Baco (2003) from whale falls off California, they coincided with studies conducted in other related habitats (e.g. Colaço et al. 2002, Levin $\&$ Michener 2002). The $\delta^{13} \mathrm{C}$ and $\delta^{15} \mathrm{~N}$ values of the whale vertebrae clearly matched those reported for other species such as southern right whales Eubalaena australis and Adélie penguins Pygoscelis adeliae (e.g. Best \& Schell 1996, Cherel 2008) that, like Antarctic minke whales, inhabit the South Atlantic/Southern Ocean and feed primarily on euphausiids. The SOM isotopic values obtained by Fujikura et al. (2017) also correspond to the SOM values of photosynthetic origin from the abyssal South Atlantic Ocean reported for other basins (e.g. see Table 1 in Holmes et al. 1996). The food source isotopic values used in our CDC and trophic position estimates were therefore reliable.

In the putative high reducing bone microhabitat, high CDC percentages $(96.45 \pm 2.96 \%$ to $94.72 \pm$ $4.41 \%$ and $80.06 \pm 3.36 \%$ to $70.33 \pm 5 \%$, respectively) and low mean TPs $(2.33 \pm 0.16$ and $1.8 \pm 0.11$, respectively) characterized nematodes ( $81.6 \%$ of total faunal abundance) and the annelid Capitella iatapiuna (15.9\% of total faunal abundance), indicating that they are mainly primary consumers of chemosynthetic bacteria (Table 1). Thus, our results suggest that $97.5 \%$ of the fauna in this microhabitat relies on chemosynthetic carbon. We found similar results in the bone microhabitats postulated to have intermediate degrees of reduction, where C. iatapiuna $(51.1 \%$ of total faunal abundance) exhibited CDC percentages of $68.6 \pm 5.26 \%$ to $53.28 \pm 7.83 \%$ and a TP of $2.12 \pm 0.05$ (Table 1). Our results confirm those from larger whale falls from the California margin measured during the sulfophilic stage, where organisms reliant on chemosynthetic carbon dominated in terms of abundance and biomass (Smith \& Baco 2003). Up to $60 \%$ of the weight of some types of whale bones, such as the caudal vertebrae studied here, may be composed of lipids with abundant proteins (Smith \& Baco 2003, Higgs et al. 2011). Anoxic conditions or very low $\mathrm{O}_{2}$ levels reported within and on the surface of bones (Huusgaard et al. 2012) suggest anoxic inner bone matrices. The chemical energy of lipids and proteins may only become available through anaerobic microbial decomposition, which produces sulfides and fuels chemosynthetic primary production (Deming et al. 1997, Smith \& Baco 2003, Treude et al. 2009). Chemosynthetic bacteria require a redox interface rather than deep, anaerobic inner-bone matrices, which increases their accessibility to metazoans. Given that we found no chemosymbiotic species in our whale fall, we suggest that free-living chemosynthetic bacteria (or the primary consumers of these bacteria) were the primary food source in these 2 microhabitats. These patterns are analogous to those described in diffusive areas of hydrothermal vents and seeps, where heterotrophic fauna mainly feed on free-living chemosynthetic bacteria or on primary microbial consumers (Van Dover \& Fry 1994, Bergquist et al. 2007, Govenar 2012, Portail et al. 2016).

In the putative low reducing skeleton microhabitat, species that did not primarily rely on CDC (from $31.73 \pm 19.03 \%$ to $0 \%$ ) and with higher TPs (from $3.83 \pm 0.05$ to $2.6 \pm 0.06$ ), namely the nematodes, Ophryotrocha sp. 3, Sirsoe cf. sirikos, Microphthalmus sp., Vrijenhoekia sp. and Osedax sp., were more abundant (55.8\% of total faunal abundance) than the consumers predominantly relying on microbial chemosynthetic production (Table 1). Even the main chemosynthetic consumer common to the 3 different skeleton microhabitats, the annelid C. iatapiuna, had a significantly lower CDC contribution in the putative low reducing microhabitat than in the higher one. These results agree with previous findings in other less sulfophilic organic falls, such as small whale skeletons, kelp and wood falls, where heterotrophic fauna mainly exploit whale, kelp and wood organic matter rather than CDC (Smith \& Baco 2003, Bernardino et al. 2010). Furthermore, some hesionid species such as Microphthalmus sp. and Vrijenhoekia 
sp., which are presumably omnivores, occurred only in the less reduced microhabitat (Alfaro-Lucas et al. 2017). A similar increase in food web complexity was reported in vent and seep environments with low fluid fluxes, where fauna benefit from more basal food sources (Portail et al. 2016). The engineering activity of the bone-eating worm Osedax sp. may cause food web differences by physically degrading the skeleton, potentially altering the anoxic inner bone environment (Alfaro-Lucas et al. 2017). These effects may, however, be much more dramatic in juvenile whale skeletons, such as in our study, which apparently experience greater amounts of Osedax bioerosion than well-calcified, lipid-rich adult skeletons (Smith et al. 2015). The effects of Osedax in whale fall communities thus greatly differs from the effects of the main physical ecosystem engineers in other similar habitats where the engineer species promote chemosynthesis (e.g. Xylophaga spp. in wood falls and vesicomyd clams in vents/seeps; Bienhold et al. 2013, Portail et al. 2016) or increase the area of influence of reduced compound fluxes and thus access to chemosynthetic food sources (Johnson et al. 1988, Govenar 2012).

Importantly, the primary chemosynthetic consumer, the dorvilleid Ophryotrocha sp. 1 (TP $=1.55 \pm 0.28$; $\mathrm{CDC}=56.95 \pm 11.31$ to $35.94 \pm 16.83$ ), co-occurs with the congeneric Ophryotrocha sp. 3, which had lower percentages of CDC $(27.71 \pm 1.23 \%$ to $0 \%)$ and a much higher mean TP $(2.6 \pm 0.06$; Table 1$)$, suggesting a primarily opportunist omnivore that also consumes whale organic matter. This whale-fall community harbored 8 different species of Ophryotrocha (Sumida et al. 2016), and the most abundant species were co-occurring sp. 1 and 3 (Alfaro-Lucas et al. 2017). Abundant and numerous species of Ophryotrocha usually inhabit whale-fall communities (Smith \& Baco 2003, Wiklund et al. 2009, 2012, Taboada et al. 2013, Ravara et al. 2015). In cold seeps, where many species of this genus also co-occur, trophic niche partitioning may partially facilitate coexistence (Levin et al. 2003, 2013), as also hypothesized for whale falls (Thornhill et al. 2012, Ravara et al. 2015). Similarly, the hesionid Pleijelius sp., a higher consumer of chemosynthetic production, showed a marked difference in CDC compared to co-occurring and presumably omnivorous confamilial species Sirsoe cf. sirikos, Microphthalmus sp. and Vrijenhoekia sp. (Table 1). Our results suggest that trophic partitioning commonly occurs among these congeneric and confamilial species. However, more research is needed to determine whether trophic niche partitioning allows these species to co-exist (Connell 1980).
Our results suggest a reduced importance of chemosynthesis for sediment-dwelling species, although some species apparently relied on $\mathrm{CDC}$, such as the annelids Neanthes shinkai, Bathyfauvelia sp. and Bathykurila cf. guaymasensis, and the squat lobster Munidopsis sp. (Table 1). This reliance is especially true for Bathykurila cf. guaymasensis, an organism known to inhabit vents and whale falls that has long been thought to rely on chemosynthetic bacteria (Glover et al. 2005; however, see Portail et al. 2016). However, the enriched $\delta^{13} \mathrm{C}$ values of Bathykurila cf. guaymasensis $(-19.7 \%$ ) compared to SOM $(-20.9 \pm$ $0.2 \%$ ), its high TP (3.75), and the low CDC percentage (14.94 to $0 \%$ ) and TP (3.42) of Bathyfauvelia sp., in combination with observations of these polynoids attacking other congeneric/familial individuals in this community (see supplementary video in Sumida et al. 2016), suggest that these species prey upon lower consumers. In fact, polynoids are frequently predators in other related communities, such as vents, although with highly variable patterns of nutrition (e.g. Tunnicliffe 1991, Van Dover 2002, Govenar 2012, Portail et al. 2016). Because of these traits and given that we analyzed only one isotopic sample per polynoid species (Table 1), our results must be interpreted with caution. The low reliance of the sedimentary fauna on CDC may relate to the small size of the carcass and to the fact that it was a juvenile whale, limiting microbial chemosynthetic activity in sediments (Smith \& Baco 2003). Furthermore, we estimated this carcass to be 5 to 10 yr old (Sumida et al. 2016), which is probably sufficient time for the degradation of much of the whale organic matter in sediments (Smith et al. 1998, Smith \& Baco 2003). These factors likely explain reasons for the absence of chemosymbiotic fauna in this community (Smith \& Baco 2003, Cunha et al. 2013). Less calcified and less lipid-rich skeletons of juvenile cetaceans may create predominantly non-chemosynthetic habitats (Smith \& Baco 2003, Lundsten et al. 2010b). Although we show that the carcass did support chemosynthesis, the low whale biomass (only the hind part of the carcass with 9 vertebrae) may have created a very localized reducing environment, hindering colonization by chemosymbiotic fauna (Sumida et al. 2016), but nonetheless supporting heterotrophs.

This small whale-fall community harbored between 3 and 4 trophic levels in total, with 2 main nutritional sources at the base of the food web. These results confirm those of another study of juvenile carcass communities, which also reported 3 trophic levels rather than the 5 that are common in larger adult carcasses (Smith \& Baco 2003). Whale bone consumers 
occupied one end of the food web; the bone-eating worm Osedax sp. exploited the skeleton, as likely did Rubyspira sp. and nematodes from the sediments and the putative low reducing skeleton microhabitats, because all had low CDC values and TPs higher than 3 (Table 1). Heterotrophic bacteria, especially sulfate reducers, may play a key role in the development of the other 'end' of the food web as chemosynthetic bacteria (primary producers) exploit the reduced inorganic compounds generated as a byproduct of their metabolism (Table 1). As reported in vents, seeps and large organic falls (Smith \& Baco 2003, Portail et al. 2016), lower $\delta^{15} \mathrm{~N}$ values suggest important local sources other than the whale organic matter and water column nitrates for primary producers. Capitella iatapiuna and nematodes of the putative highly reducing microhabitats mainly rely on these chemosynthetic bacteria, as does Ophryotrocha sp. 1 in low reducing microhabitats. These organisms form a group of primary consumers of microbial chemosynthetic production with low TPs ranging from ca. 1.5 to 2.33 (Table 1). High CDC values but a TP higher than those of the aforementioned species suggest that Pleijelius sp. is a higher consumer that also depends on chemosynthetic carbon (Table 1). We consider species with TPs ranging from ca. 2.6 to 3 with intermediate/low CDC percentage, such as hesionids, Neanthes shinkai and Munidopsis sp., as omnivores or scavengers. The CDC values and TPs in both polynoids Bathykurila cf. guaymasensis and Bathyfauvelia sp. were similar to those of whale consumers such as Osedax sp. and Rubyspira sp., but our observations suggest predatory behaviors.

Acknowledgements. We thank the Japan Agency for Marine-Earth Science and Technology (JAMSTEC), the Japanese Consulate at São Paulo, the Brazilian Ministry of Science and Technology and Innovation, the Brazilian Ministry of Foreign Affairs and the Brazilian Navy for the establishment of the Brazil-Japan Marine Science Agreement. CNPq and CAPES awarded J.M.A.L and M.S. with MSc and PhD scholarships, respectively. P.Y.G.S. was supported by a BIOTAFAPESP Grant 2011/50185-1 and CNPq Grants 302526/ 2012-9 and 301089/2016-7. We acknowledge the captain and crews of the RV 'Yokosuka' and DSRV 'Shinkai 6500' for their help at sea during the Iatá-Piuna Expedition. We also thank the Responsible Editor Dr. Paul Snelgrove, Dr. Craig R. Smith and two other anonymous reviewers, whose valuable comments greatly improved the manuscript.

\section{LITERATURE CITED}

Alfaro-Lucas JM, Shimabukuro M, Ferreira GD, Kitazato $\mathrm{H}_{\text {, }}$ Fujiwara Y, Sumida PYG (2017) Bone-eating Osedax worms (Annelida: Siboglinidae) regulate biodiversity of deepsea whale-fall communities. Deep Sea Res II 146:4-12
Allison PA, Smith CR, Kukert H, Deming JW, Bennett BA (1991) Deep-water taphonomy of vertebrate carcasses: a whale skeleton in the bathyal Santa Catalina Basin. Paleobiology 17:78-89

Baco AR, Smith CR (2003) High species richness in deep-sea chemoautotrophic whale skeleton communities. Mar Ecol Prog Ser 260:109-114

* Bergquist DC, Eckner JT, Urcuyo IA, Cordes EE, Hourdez S, Macko SA, Fisher CR (2007) Using stable isotopes and quantitative community characteristics to determine a local hydrothermal vent food web. Mar Ecol Prog Ser 330:49-65

Bernardino AF, Smith CR, Baco A, Altamira I, Sumida PYG (2010) Macrofaunal succession in sediments around kelp and wood falls in the deep NE Pacific and community overlap with other reducing habitats. Deep Sea Res I 57: 708-723

Bernardino AF, Levin LA, Thurber AR, Smith CR (2012) Comparative composition, diversity and trophic ecology of sediment macrofauna at vents, seeps and organic falls. PLOS ONE 7:e33515

* Best PB, Schell DM (1996) Stable isotopes in southern right whale (Eubalaena australis) baleen as indicators of seasonal movements, feeding and growth. Mar Biol 124: 483-494

Bienhold C, Ristova PP, Wenzhofer F, Dittmar T, Boetius A (2013) How deep-sea wood falls sustain chemosynthetic life. PLOS ONE 8:e53590

Cherel Y (2008) Isotopic niches of emperor and Adélie penguins in Adélie Land, Antarctica. Mar Biol 154:813-821

Colaço A, Dehairs F, Debruyères D (2002) Nutritional relations of deep-sea hydrothermal fields at the Mid-Atlantic Ridge: a stable isotope approach. Deep Sea Res I 49: 395-412

Connell JH (1980) Diversity and the coevolution of competitors, or the ghost of competition past. Oikos 35:131-138

* Cunha MR, Matos FL, Génio L, Hilario A, Moura C, Ravara A, Rodrigues CR (2013) Are organic falls bridging reduced environments in the deep sea? Results from colonization experiments in the Gulf of Cádiz. PLOS ONE 8: e76688

* Decker C, Olu K (2012) Habitat heterogeneity influences cold-seep macrofaunal communities within and among seeps along the Norwegian margin. Part 2. Contribution of chemosynthesis and nutritional patterns. Mar Ecol 33: 231-245

* Deming JW, Reysenbach AL, Macko S, Smith CR (1997) Evidence for the microbial basis of a chemoautotrophic invertebrate community at a whale fall on the deep seafloor: bone-colonizing bacteria and invertebrate endosymbionts. Microsc Res Tech 37:162-170

*DeNiro MJ, Epstein S (1981) Influence of diet on the distribution of nitrogen isotopes in animals. Geochim Cosmochim Acta 45:341-351

* Distel DL, Baco AR, Chuang E, Morrill W, Cavanaugh CM, Smith CR (2000) Do mussels take wooden steps to deepsea vents? Nature 403:725-726

Fanelli E, Cartes JE, Papiol V, Rumolo P, Sprovieri M (2010) Effects of preservation on the $\delta^{13} \mathrm{C}$ and $\delta^{15} \mathrm{~N}$ values of deep sea macrofauna. J Exp Mar Biol Ecol 395:93-97

*Feldman RA, Shank TM, Black MB, Baco AR, Smith CR, Vrijenhoek RC (1998) Vestimentiferan on a whale fall. Biol Bull 194:116-119

Fujikura K, Yamanaka T, Sumida YG, Bernardino AF and others (2017) Discovery of asphalt seeps in the deep 
Southwest Atlantic off Brazil. Deep Sea Res II 146:35-44

Fujiwara Y, Kawato M, Yamamoto T, Yamanaka T and others (2007) Three-year investigations into sperm whale-fall ecosystems in Japan. Mar Ecol 28:219-232

Glover AG, Goetze E, Dahlgren TG, Smith CR (2005) Morphology, reproductive biology and genetic structure of the whale-fall and hydrothermal vent specialist, Bathykurila guaymasensis Pettibone, 1989 (Annelida: Polynoidae). Mar Ecol 26:223-234

Goffredi SK, Wilpiszeski R, Lee R, Orphan VJ (2008) Temporal evolution of methane cycling and phylogenetic diversity of archaea in sediments from a deep-sea whale-fall in Monterey Canyon, California. ISME J 2:204-220

* Govenar B (2012) Energy transfer through food webs at hydrothermal vents: linking the lithosphere to the biosphere. Oceanography 25:246-255

Higgs ND, Little CTS, Glover AG (2011) Bones as biofuel: a review of whale bone composition with implications for deep-sea biology and palaeoanthropology. Proc R Soc B 278:9-17

Holmes ME, Müller PJ, Schneider RR, Segl M, Pätzol J, Wefer G (1996) Stable nitrogen isotopes in Angola Basin surface sediments. Mar Geol 134:1-12

*Huusgaard RS, Vismann B, Kühl M, Macnaugton M and others (2012) The potent respiratory system of Osedax mucofloris (Siboglinidae, Annelida) - a prerequisite for the origin of bone-eating Osedax? PLOS ONE 7:e35975

Johnson KS, Childress JJ, Hessler RR, Sakamoto-Arnold CM, Beehler CL (1988) Chemical and biological interactions in the Rose Garden hydrothermal vent field, Galapagos Spreading Center. Deep Sea Res A 35:1723-1744

Johnson SB, Warén A, Lee RW, Kano Y and others (2010) Rubyspira, new genus and two new species of bone-eating deep-sea snails with ancient habits. Biol Bull 219: 166-177

Jones WJ, Won YJ, Maas PY, Smith PJ, Lutz RA, Vrijenhoek RC (2006) Evolution of habitat use by deep-sea mussels. Mar Biol 148:841-851

Kiel S (2017) Reply to Smith et al.: Network analysis reveals connectivity patterns in the continuum of reducing ecosystems. Proc R Soc B 284:20171644

* Lau DCP, Leung KMY, Dudgeon D (2012) Preservation effects on $\mathrm{C} / \mathrm{N}$ ratios and stable isotope signatures of freshwater fishes and benthic macroinvertebrates. Limnol Oceanogr Methods 10:75-89

Levesque C, Juniper SK, Limén H (2006) Spatial organization of food webs along habitat gradients at deep-sea hydrothermal vents on Axial Volcano, Northeast Pacific. Deep Sea Res I 53:726-739

Levin LA, Michener R (2002) Isotopic evidence of chemosynthesis-based nutrition of macrobenthos. The lightness of being at Pacific methane seeps. Limnol Oceanogr 47 : 1336-1345

Levin LA, Ziebis W, Mendoza GF, Growney VA and others (2003) Spatial heterogeneity of macrofauna at northern California methane seeps: influence of sulfide concentration and fluid flow. Mar Ecol Prog Ser 265:123-139

Levin LA, Ziebis W, Mendoza GF, Bertics VJ and others (2013) Ecological release and niche partitioning under stress: lessons from dorvilleid polychaetes in sulfidic sediments at methane seeps. Deep Sea Res II 92:214-233

Levin LA, Baco AR, Bowden DA, Colaco A and others (2016) Hydrothermal vents and methane seeps: rethinking the sphere of influence. Front Mar Sci 3. doi:10.3389/ fmars.2016.00072
Lorion J, Kiel S, Faure B, Kawato M and others (2013) Adaptive radiation of chemosymbiotic deep-sea mussels. Proc R Soc B 280:20131243

* Lundsten L, Paull CK, Schlining KL, McGann M, Ussler III W (2010a) Biological characterization of a whale-fall near Vancouver Island, British Columbia, Canada. Deep Sea Res I 57:918-922

Lundsten L, Schlining, KL, Frasier K, Johnson SB, Kuhnz LA, Harvey JBJ, Clague G, Vrijenhoek RC (2010b) Timeseries analysis of six whale-fall communities in Monterey Canyon, California, USA. Deep Sea Res I 57:1573-1584

* Minagawa M, Wada E (1984) Stepwise enrichment of ${ }^{15} \mathrm{~N}$ along food chains: further evidence and the relation between $\delta^{15} \mathrm{~N}$ and animal age. Geochim Cosmochim Acta 48:1135-1140

* Miyazaki JI, de Oliveira Martins L, Fujita Y, Matsumoto H, Fujiwara Y (2010) Evolutionary process of deep-sea Bathymodiolus mussels. PLOS ONE 5:e10363

Orsi A, Johnson GC, Bullister JL (1999) Circulation, mixing, and production of Antarctic Bottom Water. Prog Oceanogr 43:55-109

* Peterson BJ, Fry B (1987) Stable isotopes in ecosytem studies. Annu Rev Ecol Syst 18:293-320

* Portail M, Olu K, Dubois SF, Escobar-Briones E, Gelinas Y, Menot L, Sarrazin J (2016) Food-web complexity in Guaymas Basin hydrothermal vents and cold seeps. PLOS ONE 11:e0162263

Post DM (2002) Using stable isotopes to estimate trophic position: models, methods, and assumptions. Ecology 83: $703-718$

R Core Team (2015) R: a language and environment for statistical computing. R Foundation for Statistical Computing. Vienna. https://www.R-project.org/

* Ravara A, Marçal AR, Wiklund H, Hilário A (2015) First account on the diversity of Ophryotrocha (Annelida, Dorvilleidae) from a mammal-fall in the deep-Atlantic Ocean with the description of three new species. Syst Biodivers 13:555-570

* Roman J, Estes JA, Morissette L, Smith CR and others (2014) Whales as marine ecosystem engineers. Front Ecol Environ 12:377-385

Shimabukuro M, Santos CGS, Alfaro-Lucas JM, Fujiwara Y, Sumida PYG (2017) A new eyeless species of Neanthes (Annelida: Nereididae) associated with a whale-fall community from the deep Southwest Atlantic Ocean. Deep Sea Res II 146:27-34

Smith CR (2006) Bigger is better: the role of whales as detritus in marine ecosystems. In: Estes JA, DeMaster DP, Doak DF, Williams TM, Robert LBJ (eds) Whales, whaling and ocean ecosystems. University of California Press, Berkeley, CA, p 286-300

Smith CR, Baco AR (2003) Ecology of whale-falls at the deep-sea floor. Oceanogr Mar Biol Annu Rev 41:311-354

Smith CR, Kukert H, Wheatcroft RA, Jumars PA, Deming JW (1989) Vent fauna on whale remains. Nature 341: 27-28

Smith CR, Maybaum HL, Baco AR, Pope RH and others (1998) Sediment community structure around a whale skeleton in the deep Northeast Pacific: macrofaunal, microbial and bioturbation effects. Deep Sea Res II 45: 335-364

Smith CR, Glover AG, Treude T, Higgs ND, Amon DJ (2015) Whale-fall ecosystems: recent insights into ecology, paleoecology, and evolution. Annu Rev Mar Sci 7:571-596

Smith CR, Amon DJ, Higgs ND, Glover AG, Young EL 
(2017) Data are inadequate to test whale falls as chemosynthetic stepping-stones using network analysis: faunal overlaps do support a stepping-stone role. Proc R Soc B 284:20171281

Sumida PYG, Alfaro-Lucas JM, Shimabukuro M, Kitazato H and others (2016) Deep-sea whale fall fauna from the Atlantic resembles that of the Pacific Ocean. Sci Rep 6: 22139

Taboada S, Wiklund H, Glover AG, Dahlgren TG, Cristobo J, Avila C (2013) Two new Antarctic Ophryotrocha (Annelida: Dorvilleidae) described from shallow-water whale bones. Polar Biol 36:1031-1045

Thornhill DJ, Struck TH, Ebbe B, Lee RW, Mendoza GF, Levin LA, Halanych KM (2012) Adaptive radiation in extremophillic Dorvilleidae (Annelida): diversification of a single colonizer or multiple independent lineages? Ecol Evol 2:1958-1970

Thubaut J, Puillandre N, Faure B, Cruaud C, Samadi S (2013) The contrasted evolutionary fates of deep-sea chemosynthetic mussels (Bivalvia, Bathymodiolinae). Ecol Evol 3:4748-4766

Thurber AR, Kröger K, Neira C, Wiklund H, Levin LA (2010) Stable isotope signatures and methane use by New Zealand cold seep benthos. Mar Geol 272:260-269

Treude T, Smith CR, Wenzhöfer F, Carney E and others

Editorial responsibility: Paul Snelgrove,

St. John's, Newfoundland and Labrador, Canada
(2009) Biogeochemistry of a deep-sea whale fall: sulfate reduction, sulfide efflux and methanogenesis. Mar Ecol Prog Ser 382:1-21

Tunnicliffe V (1991) The biology of hydrothermal vents: ecology and evolution. Oceanogr Mar Biol Annu Rev 29: 319-407

Van Dover CL (2002) Trophic relationships among invertebrates at the Kairei hydrothermal vent field (Central Indian Ridge). Mar Biol 141:761-772

*Van Dover CL, Fry B (1994) Microorganisms as food resources at deep-sea hydrothermal vents. Limnol Oceanogr 39:51-57

Van Dover CL, German CR, Parson LM, Vrijenhoek RC (2002) Evolution and biogeography of deep-sea vent and seep invertebrates. Science 295:1253-1257

Wiklund H, Glover AG, Dahlgren TG (2009) Three new species of Ophryotrocha (Annelida: Dorvilleidae) from a whale-fall in the North-East Atlantic. Zootaxa 2228: 43-56

Wiklund H, Altamira IV, Glover AG, Smith CR, Baco AR, Dahlgren TG (2012) Systematics and biodiversity of Ophryotrocha (Annelida, Dorvilleidae) with descriptions of six new species from deep-sea whale-fall and woodfall habitats in the north-east Pacific. Syst Biodivers 10: 243-259

Submitted: August 20, 2017; Accepted: May 2, 2018

Proofs received from author(s): May 18, 2018 